\title{
Relations between Phage Sensitivity and Virulence in Pseudomonas morsprunorum
}

\author{
By CONSTANCE M. E. GARRETT, J. E. CROSSE AND A. SLETTEN* \\ East Malling Research Station, Maidstone, Kent
}

(Received I9 July I973)

SUMMARY

The phage reactions and pathogenicity of English isolates of Pseudomonas morsprunorum were compared with those of isolates from other countries. Nonindigenous cherry strains resembled English cherry strains pathologically, but not all were sensitive to A7, the type-determining phage for English cherry strains. Plum strains resistant to $\mathrm{A}_{7}$ adsorbed the phage as readily as cherry strains, indicating that phage receptor materials are not involved in host specificity. Cherry strain mutants resistant to specific and/or non-specific phages showed marked attenuation of virulence, although retaining the essential pathological characters of cherry strains. The resistance of all but one of the mutants was due to failure to adsorb the homologous phage, showing that the wall structure had changed and suggesting that wall components may function as general virulence determinants in $\boldsymbol{P}$. morsprunorum.

\section{INTRODUCTION}

Pseudomonas morsprunorum causes bacterial canker of stone-fruit trees and is most important in England on the cherry (Prunus avium) and the plum (Prunus domestica). Amongst English isolates of this organism there is a strong correlation between phage sensitivity and the occurrence of virulence characters responsible for host specificity. Thus cherry isolates that are sensitive to $\mathrm{A}_{7}$ and related phages will readily infect cherry trees through leaf scars. Plum isolates, with rare exceptions insensitive to these phages, are non-virulent through cherry leaf scars; furthermore, when mixed in the same inoculum they inhibit infection by the homologous cherry isolates (Crosse \& Garrett, I963; Garrett \& Crosse, I963; Crosse \& Garrett, 1970). In this paper we examine the relationship between phage sensitivity and virulence in a selection of non-indigenous $P$. morsprunorum cherry isolates from widely separated geographical localities and describe the effects of mutation to phage resistance on the virulence of indigenous cherry isolates.

\section{METHODS}

Bacteria. Details of cultures are shown in Table I. They were maintained at $4{ }^{\circ} \mathrm{C}$ on nutrient agar plus $2 \%(\mathrm{w} / \mathrm{v})$ glycerol (NGA). Bacteria were reisolated from diseased tissues on nutrient agar plus $5 \%$ sucrose (NSA). Pseudomonas morsprunorum can be readily identified on this medium by colony characteristics (Crosse, 1959).

Phages. These were originally isolated from soils; $\mathrm{AI}_{1}, \mathrm{~A}_{3}, \mathrm{~A}_{7}, \mathrm{~A}_{9}$ and $\mathrm{A}_{32}$ with cherry strains of Pseudomonas morsprunorum as the propagating species and $\mathrm{AI}_{5}, \mathrm{~S}_{5}$ and $\mathrm{S} 6$

\footnotetext{
* Present address: Norwegian Plant Protection Institute, I432 Vollebekk, Norway.
} 
Table I. List of isolates of Pseudomonas morsprunorum

\begin{tabular}{|c|c|c|c|}
\hline Isolate & $\begin{array}{l}\text { Date of } \\
\text { isolation }\end{array}$ & Host & $\begin{array}{c}\text { Country of } \\
\text { origin }\end{array}$ \\
\hline $\mathrm{CI} 2$ & 1958 & Cherry & England \\
\hline $\mathrm{C} 9, \mathrm{C22}, \mathrm{C}_{4} 6$ & $196 r$ & Cherry & England \\
\hline CI $2 \mathrm{a}^{*}$ & 1965 & Cherry & England \\
\hline $\mathrm{C} 22 \mathrm{a}^{*}$ & 1966 & Cherry & England \\
\hline $\mathrm{c} 46 \mathrm{a}^{*}$ & 1968 & Cherry & England \\
\hline $\mathrm{C} 64, \mathrm{C} 65$ & 1963 & Cherry & Holland \\
\hline $\mathrm{C} 98, \mathrm{C} 100, \mathrm{C} 105$ & $1962-3$ & Cherry & Italy \\
\hline CI 67, CI69 & 1965 & Cherry & Canada \\
\hline $\mathrm{CI} 7 \mathrm{O}$ & 1965 & Cherry & Canada \\
\hline $\mathrm{KI}, \mathrm{K} 2, \mathrm{~K} 3$ & 1962 & Cherry & Greece \\
\hline DIO & 1960 & Plum & England \\
\hline DI7 & 1961 & Plum & England \\
\hline
\end{tabular}

* Isolates suffixed ' $a$ ' were re-isolated from experimental lesions resulting from inoculation with the isolates $\mathrm{C} 12, \mathrm{C} 22$ or $\mathrm{C} 46$.

All isolates were confirmed as $P$. morsprunorum by biochemical tests described by Garrett, Panagopoulos \& Crosse (1966) for distinguishing this organism from the related pathogen Pseudomonas syringae.

with $P$. syringae. Phages of the A7 group (AI to A9 inclusive and A32) are highly specific for cherry isolates of $P$. morsprunorum (Crosse \& Garrett, I963).

Phage typing. Phages were tested at routine test dilution (RTD) using the procedures and media (phage agar and phage broth) described by Crosse \& Garrett (1963).

Phage adsorption tests. Water suspensions of bacteria were prepared from NGA slopes and diluted to about $10^{8}$ organisms $/ \mathrm{ml}$ with phage broth. To $0.5 \mathrm{ml}$ suspension was added $0.5 \mathrm{ml}$ of phage broth containing the test phage at about $10^{8}$ p.f.u. $/ \mathrm{ml}$. The mixture was kept at $25^{\circ} \mathrm{C}$ for $30 \mathrm{~min}$ then $0.1 \mathrm{ml}$ was withdrawn and diluted into $10 \mathrm{ml}$ phage broth containing $0.1 \mathrm{ml}$ chloroform. The mixture was vigorously shaken to kill the bacteria and then assayed for unadsorbed phage by a modification of the Miles \& Misra (I938) technique. Serial dilutions of the adsorption mixture were spotted on plates of phage agar seeded with a sensitive indicator strain of Pseudomonas morsprunorum and plaques counted after overnight incubation at $25^{\circ} \mathrm{C}$.

Selection of phage-resistant mutants. A suspension in phage broth containing about $10^{8}$ sensitive bacteria $/ \mathrm{ml}$ and about $10^{9}$ p.f.u. $/ \mathrm{ml}$ of phage was spread on the surface of a phage agar plate. Bacterial colonies appearing after 4 to 7 days at $25{ }^{\circ} \mathrm{C}$ were picked-off and streaked on NSA. The process was repeated several times to ensure freedom from extrinsic phage and the final isolate was then re-tested to confirm resistance to the homologous phage.

Plant inoculations. Inoculum was prepared by quickly suspending in sterile distilled water the bacterial growth from 24 or $48 \mathrm{~h}$ cultures on NGA slopes. Suspensions were adjusted to the required concentration and then inoculated into 2-, 3- or 4-year-old branches of the cherry cultivars (cv.) Napoleon or Schrecken. Branches were inoculated through leaf scars on fruiting spurs in October or through scalpel wounds in December or January. Treatments were replicated on trees on a random basis (Crosse \& Garrett, 1966) and results recorded in the following summer, 5 to 7 months after inoculation.

Disease from leaf scar inoculations was assessed as (i) percentage of diseased spurs, (ii) canker size, and (iii) rate of leaf scar infection. Cankers were graded on an arbitrary rating scale of $\mathrm{I}$ to 5 inclusive and rate of leaf scar infection, a measure of the infectivity of the bacteria via this route, was calculated as the product (percentage of diseased spurs) $\times$ (mean 
Table 2. Phage sensitivity of isolates of Pseudomonas morsprunorum

\begin{tabular}{|c|c|c|c|c|c|c|c|}
\hline \multirow[b]{2}{*}{ Isolate } & \multirow[b]{2}{*}{ Origin } & \multicolumn{5}{|c|}{ Lysis by phage at RTD } & \multirow{2}{*}{$\begin{array}{l}\text { Adsorption of } \\
\text { phage } \mathrm{A}_{7}\end{array}$} \\
\hline & & $\mathrm{A}_{3}, \mathrm{~A}_{7}$ & A9 & $\mathrm{A}_{32}$ & AI 5 & $\mathrm{~S}_{5}, \mathrm{~S} 6$ & \\
\hline \multicolumn{8}{|c|}{ From cherry: } \\
\hline CI2 & England ) & & & & & & \\
\hline $\begin{array}{l}\mathrm{C} 22 \\
\mathrm{c} 65\end{array}$ & England & & & & & & \\
\hline $\begin{array}{l}\text { c65 } \\
\text { c167 }\end{array}$ & $\begin{array}{l}\text { Holland } \\
\text { Canada }\end{array}$ & + & + & + & + & + & + \\
\hline CI69 & Canada & & & & & & \\
\hline $\mathrm{Cr} 7 \mathrm{O}^{\circ}$ & Canada & & & & & & \\
\hline C9 & England & + & + & - & + & + & + \\
\hline c46 & England & & & & & & \\
\hline Cloo & Italy & + & + & + & - & + & + \\
\hline C105 & Italy & & & & & & \\
\hline C98 & Italy & + & - & + & - & + & + \\
\hline c64 & Holland & - & - & + & - & + & - \\
\hline $\mathrm{KI}$ & Greece & & & & & & \\
\hline $\mathrm{K} 2$ & Greece & - & - & - & + & - & + \\
\hline $\begin{array}{c}\text { K3 } \\
\text { From nlum }\end{array}$ & Greece & & & & & & \\
\hline \multicolumn{2}{|c|}{ From plum: } & - & - & - & + & + & + \\
\hline $\begin{array}{l}\text { DIO* } \\
\text { DI7 } \dagger\end{array}$ & $\begin{array}{l}\text { England } \\
\text { England }\end{array}$ & + & + & + & + & + & $\begin{array}{l}+ \\
+\end{array}$ \\
\hline
\end{tabular}

* Typical of the majority of English isolates from plum.

$\uparrow$ A rare example, previously noted (Crosse \& Garrett, 1970), of a plum isolate of cherry phage type.

canker size) (Crosse \& Garrett, I970). Results were compared by analysis of variance using an angular transformation for percentage of diseased spurs and a square root transformation for rate of leaf scar infection. Disease from wound inoculations was assessed by recording the number of successful infections and the length of the resulting cankers.

\section{RESULTS}

Comparison of indigenous and non-indigenous (NI) isolates

Phage typing and phage adsorption (Table 2). The phage reactions of C9, C12, C22 and C46 were typical of English cherry strains; all those so far examined were sensitive to phages $\mathrm{A}_{3}$ and $\mathrm{A}_{7}$ and most of them sensitive to the related phages $\mathrm{A}_{9}$ and $\mathrm{A}_{32}$ (Crosse \& Garrett, I963; Crosse \& Garrett, 1970). The reactions of DIo, insensitive to A3, A7, A9 and $\mathrm{A}_{32}$ but sensitive to $\mathrm{A}_{5} 5, \mathrm{~S}_{5}$ and $\mathrm{S} 6$, were similarly characteristic of most English plum strains (Lazar \& Crosse, 1969; Crosse \& Garrett, 1970).

Seven of the NI cherry isolates were of similar phage type to English cherry strains (Canada: CI67, CI69, CI70; Italy: c98, c100, cI05; Holland: C65). The remaining four were insensitive to phages $\mathrm{A}_{3}, \mathrm{~A}_{7}$ and $\mathrm{A}_{9}$ and in this respect resembled plum strains. They differed however from typical plum strains, e.g. DIo, in their insensitivity to $\mathrm{S}_{5}$ and S6 (Greece: KI, K2, K3) or to phage A I 5 (Holland: c64).

In the phage adsorption tests free-phage titre decreased progressively and after $30 \mathrm{~min}$ from 75 to $98 \%$ of phages were adsorbed irreversibly. With the exception of Holland c64, all the isolates adsorbed the cherry-specific phage $\mathrm{A}_{7}$, irrespective of whether they were lysed by this phage or not. The adsorption of $A_{7}$ by the plum isolate D Io has been repeated in tests with other plum isolates. 
Table 3. Comparative virulence of Pseudomonas morsprunorum isolates in leaf scar and wound inoculations of cherry (cv. Napoleon)

Leaf scars of fruiting spurs (60 to Ioo spurs/isolate) were inoculated on 12 October 1967 with $10^{6}$ bacteria $/ \mathrm{ml}$. Wounds ( 20 replicates/isolate) were inoculated on 15 December with $10^{7}$ bacteria $/ \mathrm{ml}$. Water was applied as a treatment, to estimate the background infection from 'wild' strains. Results were scored the following June.

\begin{tabular}{|c|c|c|c|c|c|}
\hline \multirow{2}{*}{\multicolumn{2}{|c|}{ Isolates }} & \multicolumn{3}{|c|}{ Leaf scar infection } & \multirow{3}{*}{$\begin{array}{l}\text { Wound infection } \\
\text { canker length } \\
(\mathrm{mm})\end{array}$} \\
\hline & & \multirow{2}{*}{$\begin{array}{c}\text { Diseased } \\
\text { spurs* } \\
(\%)\end{array}$} & \multirow{2}{*}{$\begin{array}{l}\text { Mean canker } \\
\text { size rating } \\
\text { (max. 5) }\end{array}$} & \multirow{2}{*}{$\begin{array}{l}\text { Rate of infection } \\
\quad \text { (sq. root) }\end{array}$} & \\
\hline Origin & No. & & & & \\
\hline \multicolumn{6}{|l|}{ Cherry strains } \\
\hline England & C9 & $79 \cdot 3(97)$ & $3 \cdot 77$ & 18.8 & 117 \\
\hline Holland & c65 & $80 \cdot 6(97)$ & $2 \cdot 93$ & 16.5 & 76 \\
\hline \multirow{2}{*}{ Canada } & CI69 & $72 \cdot I(9 I)$ & $2 \cdot 49$ & $\mathrm{I} 4 \cdot 8$ & 56 \\
\hline & $\operatorname{Cr} 70^{\circ}$ & $78.7(96)$ & $2 \cdot 39$ & 14.7 & 52 \\
\hline Greece & KI & $66 \cdot I(84)$ & $2 \cdot 55$ & 14.5 & 40 \\
\hline Canada & CI 67 & $68 \cdot 8(87)$ & $2 \cdot 35$ & $\mathrm{I} 4 \cdot \mathrm{O}$ & $5 \mathrm{I}$ \\
\hline Holland & c64 & $60 \cdot 0(75)$ & I.96 & $12 \cdot 0$ & 42 \\
\hline \multirow{2}{*}{ Greece } & $\mathrm{K} 2$ & $60 \cdot 1(75)$ & $1 \cdot 90$ & $\mathrm{II} \cdot 8$ & 38 \\
\hline & $\mathrm{K}_{3}$ & $46 \cdot I(46)$ & $1 \cdot 92$ & $8 \cdot 8$ & 32 \\
\hline \multirow{3}{*}{ Italy } & C98 & $26 \cdot 9(20)$ & $2 \cdot 28$ & $6 \cdot 7$ & 40 \\
\hline & $\mathrm{CroO}$ & $3 I \cdot 5(27)$ & $\mathrm{I} \cdot 7 \mathrm{I}$ & $6 \cdot 7$ & 25 \\
\hline & $\mathrm{CIO5}$ & $27 \cdot 4(25)$ & 1.58 & $6 \cdot 1$ & 20 \\
\hline \multicolumn{6}{|l|}{ Plum strain } \\
\hline England & Dro & $16 \cdot 5(8)$ & 0.97 & $3 \cdot 1$ & 86 \\
\hline Water controls & & $18.5(10)$ & $2 \cdot 04$ & $5 \cdot 6$ & 0 \\
\hline \multicolumn{6}{|c|}{$\begin{array}{l}\text { Lowest significant } \\
\text { differences }\end{array}$} \\
\hline$p=0.5$ & & I3.33 & 0.59 & $2 \cdot 04$ & - \\
\hline$p=0.0 \mathrm{r}$ & & 17.74 & 0.78 & $2 \cdot 72$ & - \\
\hline$p=0.001$ & & 23.07 & $2 \cdot 72$ & $3 \cdot 54$ & - \\
\hline
\end{tabular}

Pathogenicity tests. In leaf scar infections all the NI isolates gave significantly lower values for canker size and rate of leaf scar infection than the English reference strain, C9; the majority caused fewer diseased spurs than $\mathrm{C9}$ (Table 3). The NI isolates showed a wide range of virulence, the differences between them for all three disease parameters being frequently significant at the $p=0.00 \mathrm{r}$ level. The three Italian isolates, $\mathrm{C} 98$, croo and CI05, were the least virulent and results for these isolates did not differ significantly from 'wild'-strain infection in the controls. There was no evidence of leaf scar infection with the plum reference strain, DIO. Comparison with the controls suggests on the contrary that it reduced natural infection from 'wild' cherry strains present on the leaf surfaces of the experimental trees. This agreed with previous results (Crosse \& Garrett, 1970).

All isolates consistently infected through wounds in branches, including DIo which produced longer cankers than any of the NI cherry isolates (Table 3). The length of branch cankers, a measure of the invasive capacity of the isolates in the bark parenchyma, was positively correlated with rate of leaf scar infection $(r=0.6067 ; p=0.05)$. Only the plum strain, DIO, departed significantly from the regression line $(p=0.02$, Fig. I). When cherry isolates were considered alone the correlation was considerably improved $(r=0.8923$; $p=0.00 \mathrm{I})$ and there was also a correlation between canker length and percentage diseased 


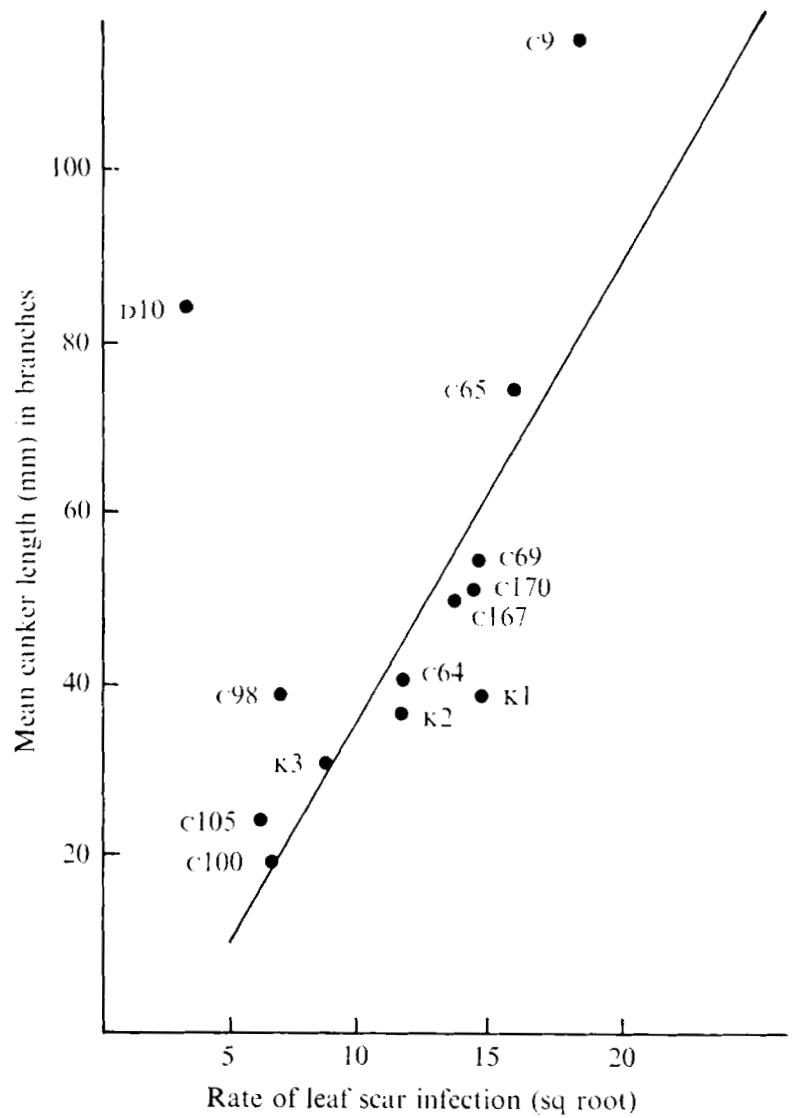

Fig. I. Relation between length of branch cankers and rate of leaf scar infection of cherry (cv. Napoleon) by Pseudomonas morsprunorum cherry strains compared with a typical plum strain, DIo. The graph is of the form $y=5 \cdot 11 x-12.88$.

spurs $(r=0.6727 ; p=0.05)$. The cherry isolates, irrespective of their origin and phage reactions (Table 2) therefore formed a pathologically similar group distinct from the plum strain, DIO. The correlation observed in cherry isolates between leaf scar infectivity and invasive capacity suggest that common virulence factors are involved in both processes.

The effect of mutation to phage resistance on virulence of English cherry isolates

Phage typing and phage adsorption. The phage reactions of the cherry isolates and of their phage-resistant mutants are shown in Table 4. Resistance of mutants was due to failure of the phage to adsorb, except in the case of C22a/s6R which adsorbed the homologous phage, $\mathbf{S 6}$, at approximately the same rate as its parent strain. Mutants selected for resistance to any one of the A7 phage group (AI, A7, A9) were resistant to all phages of the group. With one exception, C22/A7R, they were also resistant to the heterologous phage AI 5. Mutants selected for resistance to AI 5 or S6, on the other hand, were resistant to the homologous phage only. Apart from phage sensitivity no obvious cultural differences have been observed between mutants and parents. All mutants produced smooth colonies 
Table 4. Phage types of Pseudomonas morsprunorum isolates and their selected phage-resistant mutants

\begin{tabular}{|c|c|c|c|c|c|c|}
\hline \multirow{2}{*}{$\begin{array}{l}\text { Isolate; } \\
\text { mutant }\end{array}$} & \multicolumn{5}{|c|}{ Lysis by phage at RTD } & \multirow{2}{*}{$\begin{array}{c}\text { Adsorption of } \\
\text { homologous phage }\end{array}$} \\
\hline & $\mathrm{AI}^{*}$ & $\mathrm{~A}_{7}^{*}$ & A9* & AI5 & S6 & \\
\hline $\mathrm{C} 9$ & + & + & + & + & + & \\
\hline C9/AI5R & + & + & + & - & + & - \\
\hline $\mathrm{CI} 2, \mathrm{CI} 2 \mathrm{a}$ & + & + & + & + & + & \\
\hline $\mathrm{Cl} 2 / \mathrm{A} 9 \mathrm{R}$ & - & - & - & - & + & - \\
\hline CI2a/AI5R & + & + & + & - & + & - \\
\hline $\mathrm{C} 22, \mathrm{C} 22 \mathrm{a}$ & + & + & + & + & + & \\
\hline $\mathrm{C} 22 / \mathrm{A} 7 \mathrm{R}$ & - & - & - & + & + & - \\
\hline $\mathrm{C} 22 \mathrm{a} / \mathrm{s} 6 \mathrm{R}$ & + & + & + & + & - & + \\
\hline $\mathrm{c} 46, \mathrm{c} 46 \mathrm{a}$ & + & + & + & - & + & \\
\hline C46/AIR & - & - & - & - & + & - \\
\hline $\operatorname{DI} 7 \dagger$ & + & + & + & + & + & \\
\hline DI7/AIR & - & - & - & - & + & - \\
\hline Plum strains & - & - & - & + & + & \\
\hline
\end{tabular}

* Phages specific for $P$. morsprunorum cherry strains.

† A rare example, previously noted (Crosse \& Garrett, I970), of a plum isolate of cherry phage type.

Table 5. Comparative virulence of Pseudomonas morsprunorum isolates with phage-resistant mutants in leaf scar and wound inoculations of cherry (cv. Napoleon)

Leaf scars of fruiting spurs (I Io to I45 spurs/isolate) were inoculated on 1o October I965 with $10^{6}$ bacteria $/ \mathrm{ml}$. Wounds ( 18 replicates/isolate) were inoculated on 16 December with $10^{7}$ bacteria/ $\mathrm{ml}$. Water was applied as a treatment to estimate background infection from 'wild' strains.

\begin{tabular}{|c|c|c|c|c|}
\hline \multirow[b]{2}{*}{$\begin{array}{l}\text { Isolate; } \\
\text { mutant }\end{array}$} & \multicolumn{3}{|c|}{ Leaf scar infection } & \multirow{2}{*}{$\begin{array}{l}\text { Wound } \\
\text { infection: } \\
\text { mean canker } \\
\text { length }(\mathrm{mm})\end{array}$} \\
\hline & $\begin{array}{c}\text { Diseased } \\
\text { spurs } \\
(\%)\end{array}$ & $\begin{array}{l}\text { Mean canker } \\
\text { size rating } \\
(\max .5)\end{array}$ & $\begin{array}{l}\text { Rate of } \\
\text { infection } \\
\text { (sq. root) }\end{array}$ & \\
\hline $\begin{array}{l}\text { C9 } \\
\text { C9/AI } 5 \text { R }\end{array}$ & $\begin{array}{l}96 \cdot 1 \\
65 \cdot 9^{*}\end{array}$ & $\begin{array}{l}4 \cdot 33 \\
2 \cdot 76^{*}\end{array}$ & $\begin{array}{l}20 \cdot 4 \mathrm{I} \\
\mathrm{I} 3 \cdot 40^{*}\end{array}$ & $\begin{array}{l}45 \\
25\end{array}$ \\
\hline $\begin{array}{l}\mathrm{CI} 2 \\
\mathrm{CI} 2 / \mathrm{Ag} R\end{array}$ & $\begin{array}{l}95 \cdot 5 \\
25 \cdot 5 *\end{array}$ & $\begin{array}{l}3.29 \\
2.73 t\end{array}$ & $\begin{array}{c}17 \cdot 76 \\
8 \cdot 25\end{array}$ & $\begin{array}{l}20 \\
25\end{array}$ \\
\hline $\begin{array}{l}\mathrm{C} 22 \\
\mathrm{C} 22 / \mathrm{A} 7 \mathrm{R}\end{array}$ & $\begin{array}{l}94 \cdot 7 \\
23 \cdot I^{*}\end{array}$ & $\begin{array}{l}4 \cdot 23 \\
2 \cdot 59^{*}\end{array}$ & $\begin{array}{c}19 \cdot 97 \\
7.46^{*}\end{array}$ & $\begin{array}{l}42 \\
23\end{array}$ \\
\hline $\begin{array}{l}\text { C46 } \\
\text { C46/AIR }\end{array}$ & $\begin{array}{l}94^{\circ} 6 \\
27 \cdot 5^{*}\end{array}$ & $\begin{array}{l}4.01 \\
3.03 \dagger\end{array}$ & $\begin{array}{l}19.5 \mathrm{I} \\
8.8 \mathrm{I}\end{array}$ & $\begin{array}{r}19 \\
9\end{array}$ \\
\hline $\begin{array}{l}\text { DI } 7 \\
\text { DI } 7 / A I R\end{array}$ & $\begin{array}{l}91 \cdot 4 \\
32 \cdot 3^{*}\end{array}$ & $\begin{array}{l}3 \cdot 4^{2} \\
2 \cdot 44^{\dagger}\end{array}$ & $\begin{array}{c}17.60 \\
8.79^{*}\end{array}$ & $\begin{array}{l}21 \\
17\end{array}$ \\
\hline Water control & $20 \cdot 2$ & 3.09 & $6 \cdot 57$ & 一 \\
\hline
\end{tabular}

$* ; \uparrow$ Mutant differing significantly from the parent strain at $p=0.00 \mathrm{I}$ and $p=0.0 \mathrm{I}$ respectively.

on NSA and NGA with growth rates comparable to the parent strain. Some differences in fine colony structure were observed between mutants and parents but these were no greater than those occurring between parent strains. In routine biochemical tests (Garrett, Panagopoulos \& Crosse, 1966) mutants and parents were indistinguishable.

Pathogenicity tests. In leaf scar infections of the cherry cultivar Napoleon, mutants showed marked attenuation of virulence compared with the parent strains. The differences 
Table 6. Comparative virulence of Pseudomonas morsprunorum isolates and phage-resistant mutants in leaf scar inoculations of cherry (cv. Schrecken)

Leaf scars of fruiting spurs (approx. 90 spurs/isolate) were inoculated on 7 October 197I with $3 \times 10^{7}$ bacteria $/ \mathrm{ml}$. Water was applied as a treatment to estimate background infection from 'wild" strains.

\begin{tabular}{|c|c|c|c|}
\hline $\begin{array}{l}\text { Isolate; } \\
\text { mutant }\end{array}$ & $\begin{array}{l}\text { Diseased } \\
\text { spurs } \\
(\%)\end{array}$ & $\begin{array}{l}\text { Mean canker } \\
\text { size rating } \\
\text { (max. 5) }\end{array}$ & $\begin{array}{l}\text { Rate of } \\
\text { infection } \\
\text { (sq. root) }\end{array}$ \\
\hline CI2a & $97 \cdot 5$ & $2 \cdot 93$ & $16 \cdot 90$ \\
\hline $\mathrm{CI} 2 / \mathrm{A} 9 \mathrm{R}$ & $25 \cdot 8$ & $1 \cdot 38$ & $5 \cdot 97$ \\
\hline CI $2 a / A I 5 R$ & $49 \cdot 5$ & $I \cdot 80$ & $9 \cdot 44$ \\
\hline $\mathrm{c} 2 \mathrm{a}$ & $95 \cdot 2$ & $2 \cdot 78$ & $16 \cdot 27$ \\
\hline $\mathrm{C} 22 / \mathrm{A} 7 \mathrm{R}$ & $23 \cdot 2$ & $2 \cdot 00$ & 6.81 \\
\hline C22a/s6R & $7 \cdot 4$ & $I \cdot 42$ & $3 \cdot 24$ \\
\hline $\mathrm{c} 46 \mathrm{a}$ & $95 \cdot 7$ & $3 \cdot 33$ & $17 \cdot 85$ \\
\hline C46/AIR & $63 \cdot 7$ & $I \cdot 43$ & $9 \cdot 54$ \\
\hline Water control & $6 \cdot 0$ & $I \cdot 00$ & $2 \cdot 45$ \\
\hline
\end{tabular}

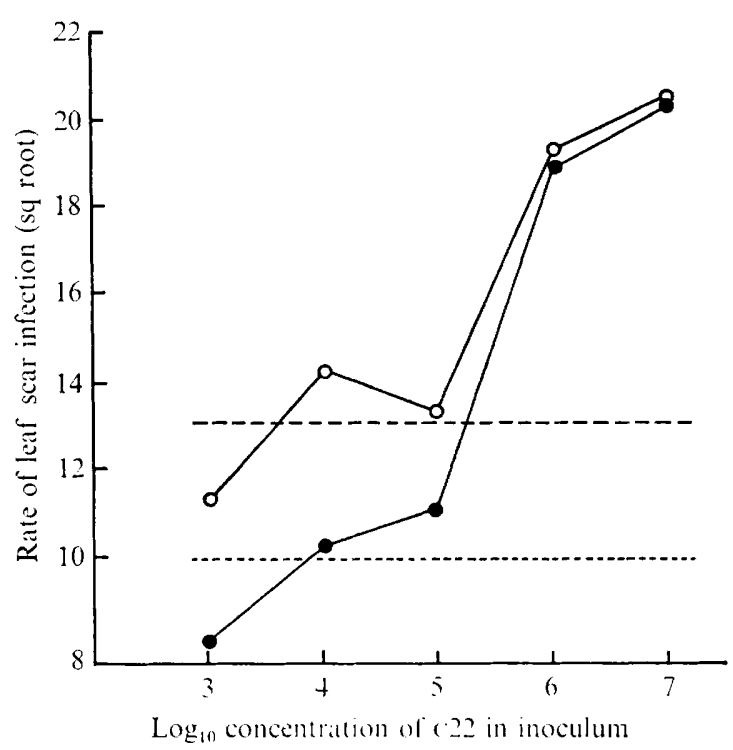

Fig. 2. Rate of cherry (cv. Napoleon) leaf scar infection resulting from different inoculum concentrations of Pseudomonas morsprunorum $\mathrm{C} 22$ in the presence and absence of a fixed concentration (about $10^{7}$ bacteria/ml) of its phage-resistant mutant, C22/A7R., C22 alone; $O$, C22 plus C22/A7R; --- , level for $\mathrm{C22}_{\mathrm{A}} \mathrm{A} \mathbf{R}$ alone; ..., level of control 'wild' strain infection.

between mutants and parents were significant for all three disease parameters, in most cases at the $p=0.001$ level (Table 5). Similar results were obtained in a second experiment on the cultivar Schrecken using a different group of isolates (Table 6). Since the differences in Schrecken were at least as great as in Napoleon the data were not analysed. Re-isolations from diseased spurs of Napoleon inoculated with C9/AI $5 R$, C22/A7R or C46/AIR yielded $85 \%, 46 \%$ and $59 \%$ respectively of isolates of the appropriate phage mutant type. The mutants were therefore stable during host passage, as are parent cherry strains (Crosse \& Garrett, I966). In wound inoculations of Napoleon branches all mutants except CI2/A9R caused smaller cankers than the parent strain (Table 5). 


\section{The effect on leaf scar infection of adding a phage-resistant mutant to the cherry strain inoculum}

Strain C22 inoculated to cherry leaf scars at a range of concentrations gave an expected sigmoid dosage response relationship (Crosse \& Garrett, 1970). When the mutant C22/A7R was added to the $\mathbf{C 2 2}$ inocula, at a constant high level, there was no sign of the inhibitory effect associated with the presence of plum strains in the inocula. On the contrary, the rate of infection was significantly increased when the mutant to parent ratio was I00: I ( $p=0.0 \mathrm{I}$ level) or higher ( $p=0.00$ I level) (Fig. 2). The mutant alone caused some infection but values for all three disease parameters were significantly less $(p=0.00 \mathrm{I}$ level $)$ than for $\mathrm{C22}$ at the same concentration.

\section{DISCUSSION}

In previous work with indigenous plum and cherry strains of Pseudomonas morsprunorum, only those sensitive to phage $A_{7}$ (all cherry strains and very rare plum strains such as DI 7 ) were infective through cherry leaf scars, suggesting a possible link between phage sensitivity and the pathological characters responsible for host specificity in these organisms (Crosse \& Garrett, 1970). This is not supported by the present experiments with phage-resistant mutants and non-indigenous cherry strains. A significant proportion of these were insensitive to A7 yet they behaved in pathological tests as cherry and not as plum strains. There was also no relationship between host specificity in $P$. morsprunorum and adsorption of phage A7. One of the non-indigenous cherry strains, $\mathrm{C6}_{4}$, and several of the mutants failed to adsorb A7, while plum strains apparently adsorb it as readily as 'wild' cherry strains.

The failure of plum strains to infect through cherry leaf scars and their inhibitory effect on homologous cherry strains in mixed inocula have been attributed to the induction of a hypersensitivity reaction in cherry tissues (Crosse \& Garrett, 1970). The results of the phage adsorption experiments indicate that this reaction is not due to the presence in the walls of plum strains of material acting as specific phage receptor sites. This is confirmed by experiments with other plant pathogenic Pseudomonas spp. to be reported later. Several of these showed inhibitory activity similar to plum strains in mixed infection experiments but were unable to adsorb A7. Other work suggests that the factors responsible for the inhibitory effect of plum strains may not be located in the bacterial wall. We have been unable to reproduce the specific inhibitory effect of plum strains with wall preparations, or to induce a hypersensitivity reaction in tobacco leaves with these preparations (Klement, 1963).

The experiments with phage-resistant cherry strain mutants suggest that there may be wall components involved in the pathogenicity of Pseudomonas morsprunorum although not in its host specificity. The attenuation of virulence following mutation to phage resistance occurred with resistance to AI 5 and S6 as well as to the cherry strain specific group of A7 and related phages. All mutants retained the essential pathological characters of cherry strains. Thus, the reduced leaf scar infectivity of mutants was accompanied in most instances by reduced invasive capacity in wound inoculations, indicating a correlation between these two activities similar to that observed for 'wild' cherry strains (Fig. I). Also, in mixed infection experiments with its parent strain, the mutant $\mathrm{C22} / \mathrm{A} 7 \mathrm{R}$ showed none of the inhibitory activity associated with the presence of plum strains in the inocula (Fig. 2). It seems clear therefore that the decreased virulence of mutants was due to a change in characters other than those responsible for the host specificity of P. morsprunorum. Six 
of the seven mutants tested failed to adsorb the homologous phage (Table 4 ) showing that there had been some change from the parent in phage receptor material in the bacterial wall. Using procedures for extracting lipopolysaccharides from bacterial walls (Westphal \& Jann, 1965), we have recently obtained materials that inactivate phages specifically in vitro. Keen \& Williams (I97I) reported the isolation of a lipopolysaccharide complex from a related pathogen, Pseudomonas lachrymans, and showed that this induced water soaking in the leaves of its natural host, the cucumber. Hoitink \& Bradfute (1972) could not induce disease in tobacco using gymnoplasts of Pseudomonas tabaci and suggested therefore that pathogenicity determinants were located in the wall of the pathogen. It is plausible to speculate from our work that the wall of $P$. morsprunorum contains materials which play a role in pathogenicity analogous to the lipopolysaccharide endotoxins of the Enterobacteriaceae. The fact that one of the mutants, C22a/s6R, showed marked attenuation of virulence without any loss of phage adsorptive capacity (Table 4) does not necessarily conflict with this theory, since the phage resistance of this mutant may result from changes in macromolecular wall components affecting phage penetration. We have no evidence of this, however, and the results with other mutants must therefore be interpreted with caution. Changes in wall structure and virulence may be no more than associated characters resulting from some other change in the mutants, i.e. in basic carbohydrate metabolism.

\section{REFERENCES}

Crosse, J. E. (1959). Bacterial canker of stone-fruits. IV. Investigation of a method for measuring the inoculum potential of cherry trees. Annals of Applied Biology 47, 306-317.

Crosse, J. E. \& GarretT, C. M. E. (I963). Studies on the bacteriophagy of Pseudomonas morsprunorum, Ps. syringae and related organisms. Journal of Applied Bacteriology 26, I 59-177.

Crosse, J. E. \& Garrett, C. M. E. (I966). Bacterial canker of stone-fruits. VII. Infection experiments with Pseudomonas morsprunorum and P. syringae. Annals of Applied Biology 58, 3I-4I.

Crosse, J. E. \& Garrett, C. M. E. (I970). Pathogenicity of Pseudomonas morsprunorum in relation to host specificity. Journal of General Microbiology 62, 315-327.

Garrett, C. M. E. \& Crosse, J. E. (1963). Observations on lysogeny in the plant pathogens Pseudomonas morsprunorum and Ps. syringae. Journal of Applied Bacteriology 26, 27-34.

Garrett, C. M. E., Panagopoulos, C. G. \& Crosse, J. E. (1966). Comparison of plant pathogenic pseudomonads from fruit trees. Journal of Applied Bacteriology 29, 342-356.

Hortink, H. A. J. \& Bradfute, O. E. (I972). Mechanisms of disease initiation by Pseudomonas tabaci. In Proceedings of the Third International Conference on Plant Pathogenic Bacteria, Wageningen, 1971, pp. 55-58. Edited by H. P. Maas Geesteranus.

Keen, N. T. \& Williams, P. H. (I97I). Chemical and biological properties of a lipomucopolysaccharide from Pseudomonas lachrymans. Physiological Plant Pathology r, 247-264.

KLEMENT, Z. (1963). Method for the rapid detection of the pathogenicity of phytopathogenic pseudomonads. Nature, London 182, I813-1814.

LAZAR, I. \& CRosSE, J. E. (I969). Lysogeny, bacteriocinogeny and phage types in plum isolates of Pseudomonas morsprunorum Wormald. Revue Roumaine de Biologie 14, 325-333.

Miles, A. A. \& MisRA, S. S. (I938). The estimation of the bactericidal power of the blood. Journal of Hygiene 38, 732-742.

WeSTPHAL, O. \& JANN, K. (I965). Bacterial lipopolysaccharides. Extraction with phenol-water and further applications of the procedure. In Methods in Carbohydrate Chemistry, vol. 5, p. 83. Edited by R. L. Whistler. New York and London: Academic Press. 